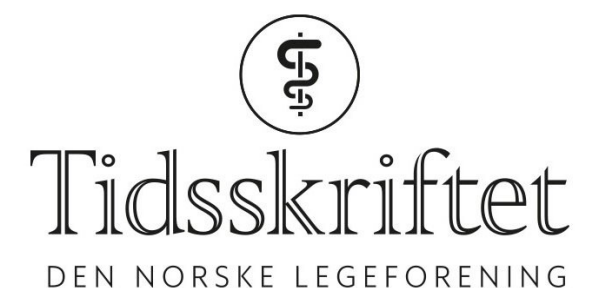

DEN NORSKE LEGEFORENING

\title{
Tilgang til helsedata er ikke lett
}

DEBATT

\section{J $\varnothing \mathrm{RGEN}$ G. BRAMNESS}

E-post: j.g.bramness@medisin.uio.no

Jørgen G. Bramness er spesialist i psykiatri og seniorforsker ved Nasjonal kompetansetjeneste for samtidig rusmisbruk og psykisk lidelse (NK-ROP) ved Sykehuset Innlandet på Hamar og Professor II ved Institutt for klinisk medisin, Det helsevitenskapelige fakultet, Universitetet i Troms $\emptyset$ - Norges arktiske universitet.

Forfatteren har fylt ut ICMJE-skjemaet og oppgir ingen interessekonflikter.

Selv om helseministeren har lovet at tilgangen til helsedata skal bli enklere, har dette fortsatt ikke skjedd.

Norge har fantastiske helseregistre. I mars 2018 sa helseminister Bent Høie at det skulle bli lettere å få tilgang til dataene (1). Det har enda ikke skjedd. Jeg har skrevet en del vitenskapelige artikler med data fra Reseptregisteret. Registeret har siden 2004 vært en kilde til viktig kunnskap om bruken og effekten av legemidler. I november 2018 kom jeg på en idé til et prosjekt: Vi hadde medikament A som var godt, men som også hadde problematiske sider, spesielt brukt sammen med legemiddel B. Det skjedde dessverre litt for ofte. Så kom legemiddel C. Vi var litt skeptiske til det fordi det ble hevdet å være veldig godt, men hadde likevel noen uheldige sider. Etter noen år ønsket vi å undersøke om legemiddel C virkelig reduserte bruken av legemiddel A, uten å øke bruken av legemiddel B.

Jeg skrev protokollen i løpet av noen dager. To kolleger ville være med. Den ene kan mye om pasientgruppen og spesielt medikament A og C, mens jeg kan mye om B og C. Den andre kollegaen har publisert mye fra Reseptregisteret og er en god statistiker.

Reseptregisteret ble i sin tid opprettet med tanke på forskning. Det inneholder alle utleverte resepter. Alle som får forskningsfiler fra Reseptregisteret, får taushetsbelagte opplysninger, og det er ikke samtykkebasert. Mitt prosjekt var midt i blinken for det Reseptregisteret er ment å bidra med. Kobling av datakilder kan være litt kinkige, i og med at ulike regler gjelder for ulike registre og man bruker fødselsnummer. Da må en tredjepart inn for å sikre anonymitet av data. Mitt prosjekt innebar ingen slik kobling.

Jeg spurte en kollega om man må søke Regional komité for medisinsk og helsefaglig forskningsetikk (REK) om dette. Det har vært veldig varierende. En stund behøvde man ikke søke, så måtte man, så måtte man ikke, så var andre inne osv. Svaret var at jeg måtte søke komiteen og i tillegg søke personvernombudet.

\section{Søknadsmølla}

Jeg sendte en søknad til regional etisk komité 11. desember 2018. Jeg slet litt med skjemaet fordi jeg måtte begrunne hvorfor jeg ikke skulle innhente samtykke. Det kunne jeg jo ikke innhente om jeg så ville. Men jeg svarte så godt jeg kunne. Jeg fant ingenting om 
taushetsplikten i skjemaet. Jeg fikk beskjed om at søknaden var mottatt 18. desember, og 8. februar 2019 fikk jeg beskjed om at prosjektet var godkjent. Jeg søkte personvernombudet 13. desember 2018 og fikk godkjenningsbrev 16. februar 2019. Prosjektet burde godkjennes ut fra regelverket.

Jeg sendte søknad til Reseptregisteret, men slet litt fordi de spurte etter en del opplysninger jeg ikke visste noe om. Jeg tenkte at dette ble dekket av Reseptregisterets intensjon samt prosjektbeskrivelsen og svarene fra regional etisk komité og personvernombudet. Dette sendte jeg til Reseptregisteret samme dag. 21. februar fikk jeg svar om at de ikke ville behandle søknaden før de fikk mer informasjon: For det første en bekreftelse fra regional etisk komité om fritak fra taushetsplikten, for det andre måtte jeg vise hvilket nasjonalt rettsgrunnlag som lå til grunn.

Jeg ba regional etisk komité presisere dette med taushetsplikten, og tre dager senere fikk jeg denne presiseringen. Personvernombudet svarte at de strevde med å skjønne hva som ble etterspurt, men kom med en uttalelse de håpet at kunne brukes. Jeg sendte dette til Reseptregisteret, og 1. mars fikk jeg svar. Her formulerte Reseptregisteret mer nøyaktig det de ønsket fra personvernombudet. Dette sendte jeg til personvernombudet, som 3. mars sendte meg en ny presisering de håpet jeg kunne bruke. Reseptregisteret ga også beskjed om at regional etisk komité måtte godta at jeg fikk opplysninger om medikament B, fordi det ikke var presisert i vedtaket. Det hadde de selvsagt rett i. Det stod riktignok i prosjektbeskrivelsen, og Reseptregisteret hadde hele tiden omtalt at de skulle utlevere data om B, men det stod ikke eksplisitt i komiteens vedtak. Jeg sendte derfor prosjektendringssøknad til regional etisk komité 10. mars.

\section{Alle har gjort jobben sin}

Nå skriver vi 18. mars. Jeg kommer til å få data; dette er enkle data som Reseptregisteret er ment å gi ut. Alle som får data fra Reseptregisteret, må få fritak fra samtykke og taushetsplikt. Ingen har gjort noe galt, bortsett fra meg som sikkert har glemt og oversett ting. Alle har vært vennlige og imøtekommende og har gjort jobben sin. Men jeg har sendt 13 dokumenter til regional etisk komité, fem dokumenter til personvernombudet og sju dokumenter til Reseptregisteret. Og flere vil bli sendt. Jeg har sendt ca. 40 e-poster, hatt sju telefonsamtaler og 2-3 møter ansikt til ansikt. Det er i tillegg en masse detaljer jeg ikke har beskrevet.

Det er enda ikke helt lett å få tilgang til helsedata i Norge.

\section{LITTERATUR:}

1. Røise MB. Nå skal det bli enklere å få tilgang til norske helsedata. Bygger ny plattform til 150 millioner kroner. digi.no 22.3.2018.

https://www.digi.no/artikler/na-skal-det-bli-enklere-a-fa-tilgang-til-norske-helsedata-bygger-ny-plattfo rm-til-15o-millioner-kroner/433426 (17.3.2019).

Publisert: 24. april 2019. Tidsskr Nor Legeforen. DOI: 10.4045/tidsskr.19.0234

Mottatt 18.3.2019, godkjent 26.3.2019.

(C) Tidsskrift for Den norske legeforening 2020. Lastet ned fra tidsskriftet.no 